\title{
CLINICAL AND MORPHOLOGICAL STUDY OF CALF ENLARGEMENT FOLLOWING S-I RADICULOPATHY
}

\author{
OSVALDO J. M. NASCIMENTO * - MARCOS R. G. DE FREITAS * \\ MYRIAN D. HAHN ** - ABELARDO Q. C. ARAÚJO *
}

\begin{abstract}
SUMMARY - Calf enlargement following sciatica is a rare condition. It is reported the case of a 28-year-old woman who complained of repeated episodes of lower back pain radiating into the left buttock and foot. One year after the beginning of her symptoms, she noticed enlargement of her left calf. $X$-ray studies disclosed $1^{\wedge}-9$, disk degeneration. EMG showed muscle denervation with normal motor conduction velocity. Open biopsies of the gastrocnemius muscles were performed. The left gastrocnemius muscle showed hypertrophic type 2 fibers in comparison with the right gastrocnemius. Electron microscopy showed mildly increased number of mitochondria in these fibers. A satisfactory explanation for denervation hypertrophy has yet to be provided.
\end{abstract}

KEY WORDS: Muscle hypertrophy, calf enlargement, radiculopathy, muscular biopsy, electron microscopy.

Estudo clínico e morfológico da hipertrofia de panturrilha no curso de radiculopatia

RESUMO - A hipertrofia da panturrilha no curso de ciática é raramente observada. É relatado o caso de uma paciente com 28 anos de idade que apresentou episódios repetidos de dor lombar irradiada para nádega e pé esquerdos. Um ano após o início dos sintomas, notou aumento da panturrilha esquerdia. Estudos radiográficos revelaram degeneração do disco de L*-S . O exame eletromiográfico mostrou desnervação muscular com velocidade de condução 51

motora normal. Foram realizadas biópsias dos músculos gastrocnêmios. No esquerdo notou-se hipertrofia das fibras tipo 2 , em comparação ao gastrocnêmio direito. A microscopia eletrônica revelou aumento do número de mitocôndrias nas fibras hipertrofiadas. Explicação satisfatória para a hipertrofia muscular na vigência de desnervação ainda não foi definida.

PALAVRAS-CHAVE: hipertrofia muscular, aumento da panturrilha, radiculopatia, microscopia eletrônica.

Hypertrophy of the calf associated with sciatica is a rare condition ${ }^{14}$. Muscle hypertrophy following denervation has been studied in cases of traumatic lesion of peripheral nerve 7, chronic spinal atrophies 3,12,16, postpoliomyelitis syndromes, and polyneuropathies 4,5,15. Lhermitte and AlbessardS were the first to report a case of hypertrophy of the calf during the course of sciatica. Lapresle et al.s, in 1973, described the first muscle biopsy study in a similar case. Other morphological studies were later performed io,i3 showing hypertrophy of both fiber types, specially type 1 fibers.

We describe clinical and biopsy findings (light and electron microscopy) in a patient with calf muscular hypertrophy following a $S_{x}$ radiculopathy.

Departments of «Clinicai Medicine (Neurology) and **Rathology (Neuropathology), Hospital Universitário Antonio Pedro, Universidade Federal Fluminense (UFF).

Dr. Osvaldo J. M. Nascimento - Rua Mal. Ramon Costilla 251/903 - 22290 Rio de Janeiro RJ Brasil. 
NCS, a 82-year-old right-handed woman had complained of repeated episodes of low back pain radiating into the left buttock and foot since February 1988. One year lather she noticed a slow enlargement of her left calf. Painful cramps occasionally ocurred. No preceding physical training was reported. Family history for neuromuscular disease was negative. The neurological examination revealed diminished left plantar flexion (grade 4/5 MRC) and eversion of the foot (grade 4/5 MRC) on this side. The strenght in other muscle groups was normal. The ankle jerk was absent on the left. The calf on that side was - enlarged with a circumference of $40 \mathrm{~cm}$; on the opposite side circumference was $34 \mathrm{~cm}$ (Fig. 1) $X$-ray studies disclosed Li - $S$, disk degeneration. The electromyogram showed normal motor conduction velocity, absexice 51

of the $H$ reflex latency on the left side, positive sharp waves and fibrillation in the left gastrocnemius muscle, and positive sharp waves in the lower lumbar left paraspinal muscles. No pseudomyotonic discharges were registered.

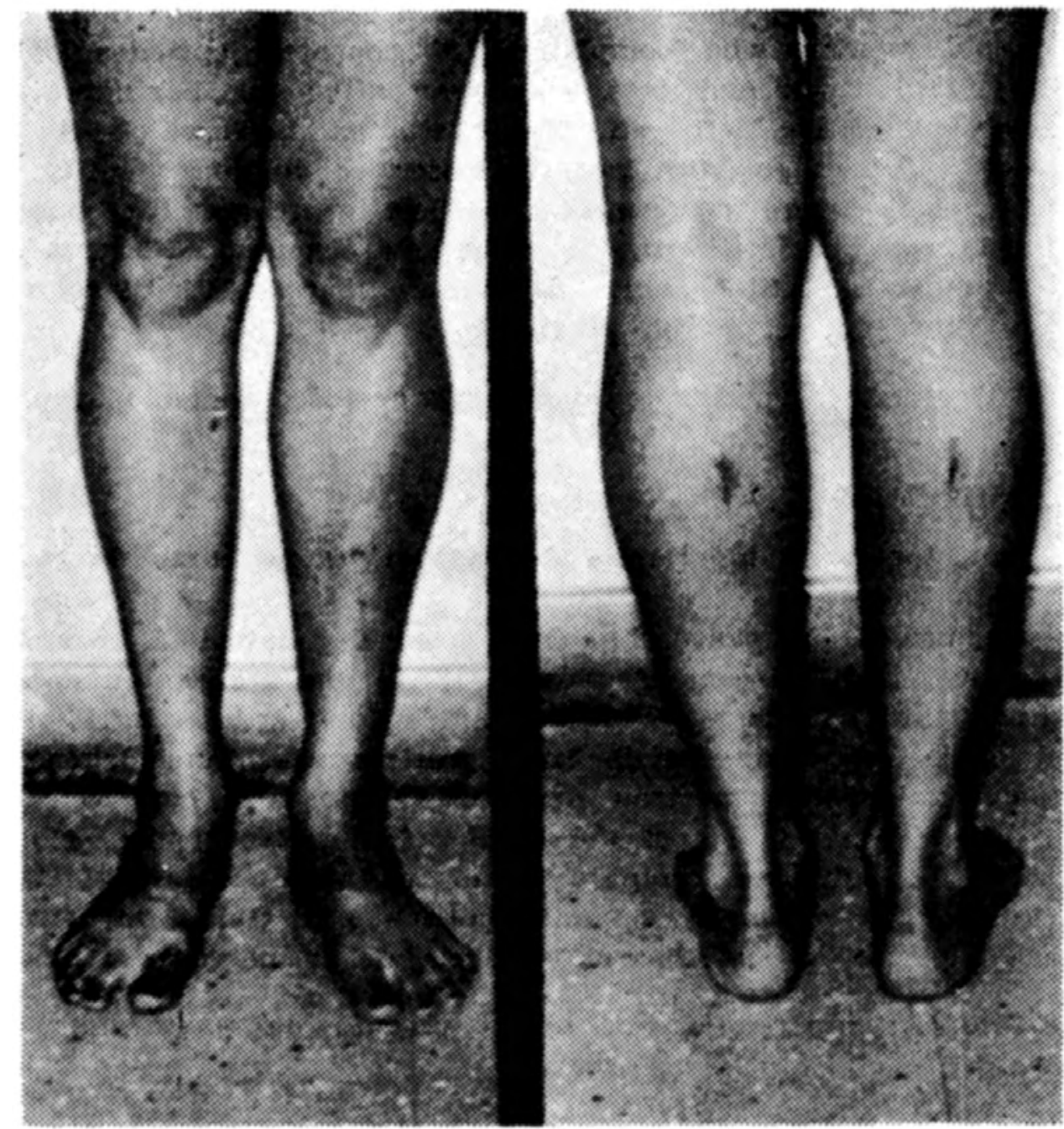

Fig. 1. Case NCS: left calf enlargement.

Muscle biopsies of the gastrocnemius muscle were performed on both calves. Formalin fixed and paraffin-embedded specimens were stained with hamatoxylin-eosin (HE), Gomori trichrome, and periodic acid of Schiff (PAS). A second specimen of muscle was frozen in liquid nitrogen and stained for myofibrillar adenosine triphosphatase (A TPase preincubation at ph 9.4 and 4.6) and succino-dehydrogenase (SDH). A modified Gomori trichrome and HE were also used on the frozen material. A third specimen was processed for electron microscopy.

\section{R E S U L T S}

The left gastrocnemius muscle showed groups of atrophied fibers and normal sized as weill as hypertrophied type 2 fibers, in comparison with the right gastrocnemius muscle (Fig. 2). Some of these hypertrophied fibers presented intense reaction in the periphery on SDH. These fibers remained polygonal. Myopathic features were not observed. Nonspecific changes were found by electron microscopy. Mitochondria had a normal aspect but appeared mildy increased in number in the hypertrophied fibers (Fig. 3) when compared with the normal fibers of the right muscle. 

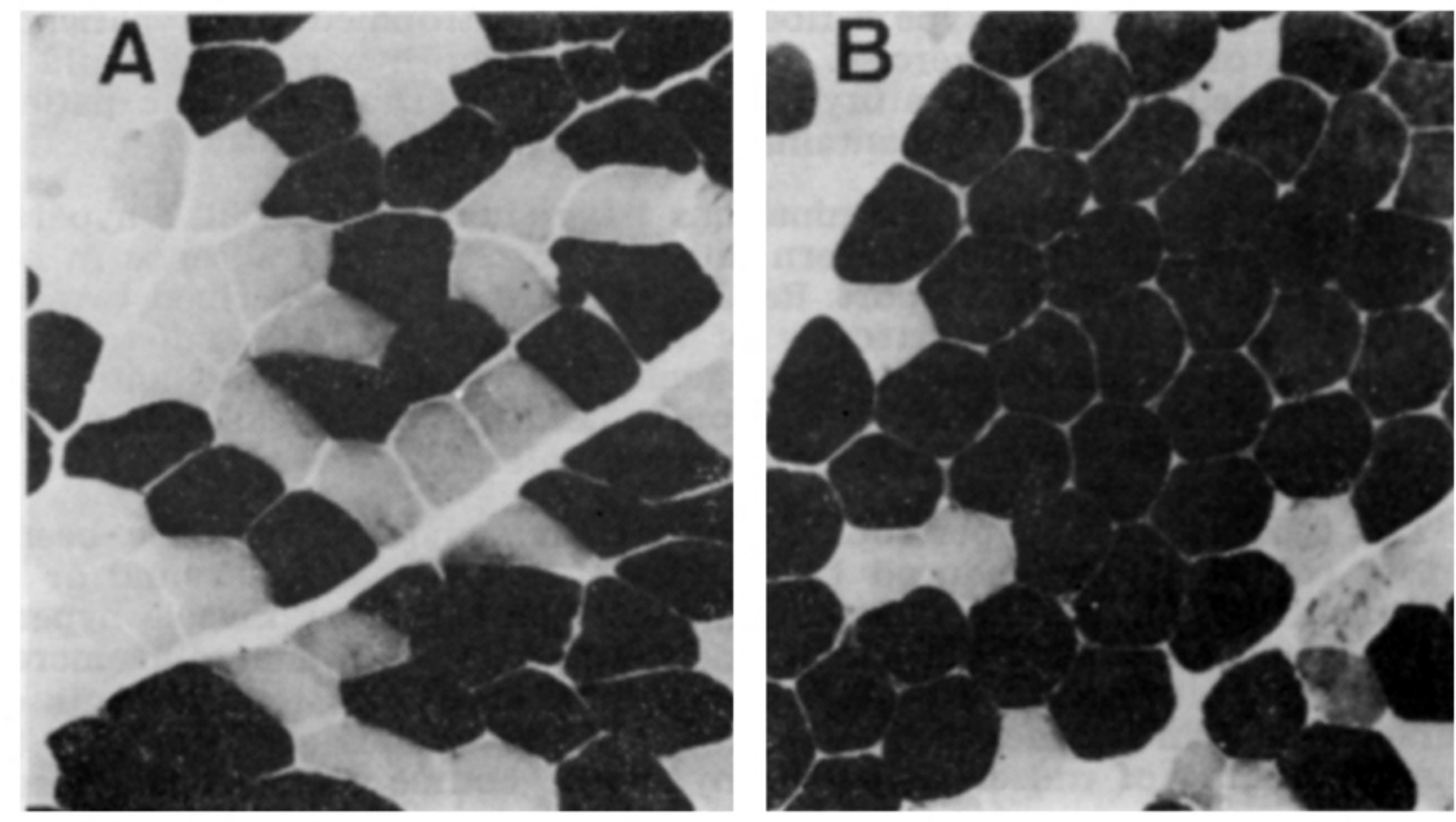

Fig. 2. Case NCS: gastrocnemius muscle biopsies. In A (normal sized calf) the mosaic pattern is preserved. In $B^{\prime}$ (hypertrophied calf) sample with type grouping fibers, belonging to type $2(A$ and $B:$ ATPase pH 9.4, 40X).
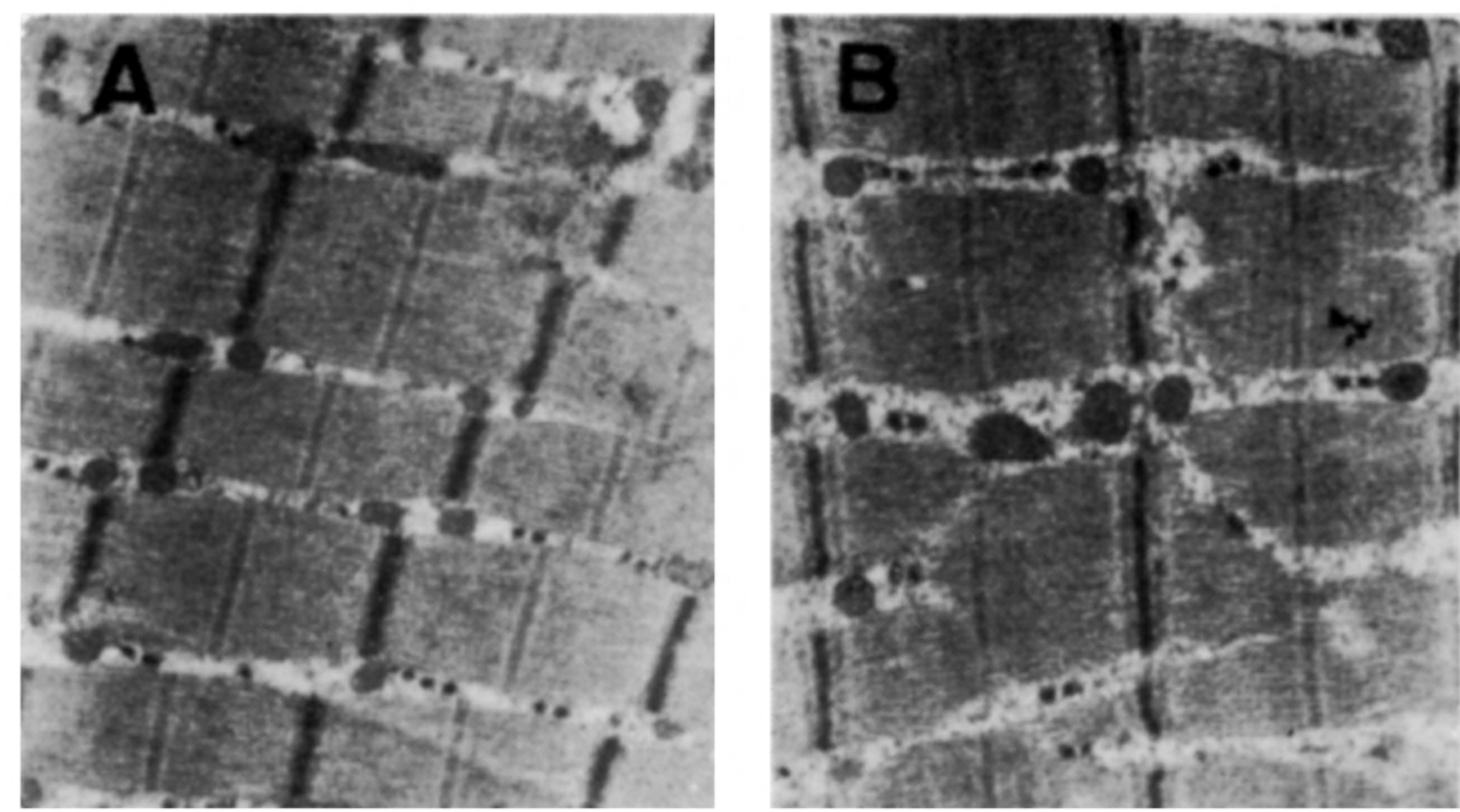

Fig. 3. Case NCS: electron micrographs (EM) of normal right (A) and left hypertrophied (B) gastrocnemius muscles. Reduced number of sarcomeres is present in $B$, when compared to $A$. $A$ mild increase in the number of mitochondria appears to occur in $B$ ( $A$ and $B: E M, \times 30.000)$.

\section{COMMENTS}

In our patient true hypertrophy of the muscle of one calf developed progressively following $S_{x}$ radiculopathy as described by Lapresle et al. ${ }^{6}$. There was hypertrophy of type 2 fibers exclusively with less marked signs indicating denervation. The hypertrophy of the left calf was related to the increased diameter of type 2 fibers when compared to the fibers of the right side. Previous reports of muscle biopsy findings in calf hypertrophy after partial nerve lesions concerning $\mathrm{Si}$ root revealed enlargement of both fibers type, mainly of type $\mathbf{1}^{10} \gg^{14}$ Predominant hypertrophy of type 2 fibers have also been reported ${ }^{11}$. The proximity of atrophic fibers with those with compensatory hypertrophy could make clear the inequality of muscle fibers $\operatorname{size}^{14}$. In our case and in the report 
of Bernât and $\operatorname{Ochoa}^{1}$ only type 2 fibers were hypertrophied. Their patient had a 2 year period of physical exercise. This type 2 fiber hypertrophy could be undoutedly regarded as compensatory work-induced i.io. Diversely, our patient had no exercise program but she mantained her activity.

The electrophysiological examinations have shown a muscular hyperactivity related to the pseudomyotonic pattern in some cases 6,10 , and absence in others $i$. ii, i4 as occurs in the present report. Recently Mattle et al.' described two patients with isolated neurogenic hypertrophy of the trapezius muscle due to accessory nerve injury and a patient with neurogenic hypertrophy of the anterior tibial muscle due to chronic radicular lesion of $L_{4}$. EMG in these cases showed dense continuing spontaneous discharges of complex potentials.

The type 1 fibers hypertrophy observed in some reports have been interpreted as compensatory, induced by lesions of synergic muscles and/or muscle compartments $1^{4}$. Our findings also suggest that compensatory muscle hypertrophy of both type could appear in partial denervation 1,6,10,11. The mild increase in the number of mitochondria could express higher oxydative requirements of type 2 fibers on this chronic active denervation. Further studies are necessary for the full understanding of muscle hypertrophy in the course of neurogenic lesions.

\section{RE F E R E N C ES}

1. Bernât JL, Ochoa JL. Muscle hypertrophy after partial denervation: a human case. J Neurol Neurosurg Psychiatry 1978, 41:719-725.

2. Bertorini TE, I gar ash i M. Post poliomyelitis muscle pseudohypertrophy. Muscle Nerve 1985, 8:644-649.

3. Bouwsna G, Van Wijngaarden GK. Spinal muscular atrophy and hypertrophy of the calves. J Neurol Sci 1980, 44:275-279.

4. De Visser M, Hoogendijk JE, De Visser BWO, Verbeeten BJ. Calf enlargement in hereditary motor and sensory neuropathy. Muscle Nerve 1990, 13:40-46.

5. Korczyn AD, Kuritzky A, Sandbank U. Muscle hypertrophy with neuropathy. J Neurol Sci 1978, 36:399-408

6. Lapresle J, Fardeau M, Said G. L'hypertrophie musculaire vraie secondaire à une atteinte nerveuse périphérique: étude clinique et histologique d'une observation d'hypertrophie du mollet consécutive à une sciatique. Rev Neurol (Paris) 1973, 128;153-160.

7. Lhermite J. Hypertrophie des muscles de la jambe consécutive à une lésion du nerf sciatique par balle. Rev Neurol (Paris) 1918, 33:56-58.

8. Lhermitte J, Albessard M. L'hypertrophie musculaire de l'a jambe dans la névrite sciatique. Rev Neurol (Paris) 1932, 83:78-90.

9. Mattle HP, Hess CW, Ludin H-P, Mumenthaler M. Isolated muscle hypertrophy as a sign of radicular or peripheral nerve injury. J Neurol Neurosurg Psychiatry 1991, 54:325329.

10. Mielke U, Ricker K, Emser W, Boxler K. Unilateral calf enlargement following S radiculopathy. Muscle Nerve 1982, 5:434-438.

11. Montagna P, Martinelli P, Rasi F, Cirignotta F, Govoni E, Lugaresi E. Muscular hypertrophy after chronic radiculopathy. Arch Neurol 1984, 41:397-398

12. Pearn JH, Hudgson P. Anterior-horn cell degeneration and gross calf hypertrophy with adolescent onset. Lancet 1978, 1:1059-1061.

13. Ricker K, Rohkamm R, Moxley RT. Hypertrophy of the calf with S radiculopathy. Arch Neurol 1988, 45:660-664.

14. Serratrice G, Pellissier JF, Marini JF, Valentin-Leccese P. Un cas de sciatique avec hypertrophie du mollet. Rev Neurol (Paris) 1989, 145:474-477.

15. Valenstein E, Watson RT, Parker JL. Myokymia, muscle hypertrophy and percussion myotonia in chronic recurrent polyneuropathy. Neurology 1978, 28:1130-1134.

16. Yamada $M$, Kano $M$, Chida $K$, Furukawa $T$, Tsukagoshi $H$. A symptomatic benign familial spinal muscular atrophy with hypertrophy of the calves and high creatine kinase levels. J Neurol Neurosurg Psychiatry 1988, 51:452-453. 